\title{
PHOSPHORUS REMOVAL FROM IRAQI TREATED WASTEWATER USING ALUM SLUDGE
}

\author{
${ }^{*}$ Aseel M. Alwan ${ }^{1}$
}

Mohammad Ali Rashid ${ }^{1}$

1) Environmental Engineering Department, College of Engineering, Mustansiriyah University, Baghdad, Iraq

\begin{abstract}
Phosphorus is one of the most important nutrients affecting the eutrophication, so its treatment is the most important thing that must be taken before wastewater is dumped into water bodies. This paper presents a study on phosphorous removal by adsorption with oven-dried-alum-sludge (ODAS) that was collected from Baqubah treatment plant (Iraq) and preheat at $105^{\circ}$ C, cool down at room temperature, and crushed into small particles of $(0.8-5) \mathrm{mm}$. The effect of ODAS studied with doses of $1.25-20 \mathrm{~g} / \mathrm{l}$ and found that the higher the dose of adsorbent, the higher the percentage of phosphorous removal. Contact time also studied its effect on phosphorous removal and found that it has a clear effect on the adsorption process, as the percentage of phosphorous removal efficiency increased with increasing contact time. The optimum dosage of ODAS was $10 \mathrm{~g} / \mathrm{l}$ and contact time $180 \mathrm{~min}$ with phosphorous removal efficiency $(98 \%, 99 \%, 97 \%$, and $97 \%)$ for initial concentration of $(5,10,15$, and 20$) \mathrm{mg} / \mathrm{l}$ of phosphorus.
\end{abstract}

Keywords: phosphorous removal, wastewater treatment, adsorption, alum sludge

\section{Introduction}

One of the most common issues that related with lakes and inland seas is the eutrophication. The major reason of this phenomenon is the presence of the nutrients (nitrogen, phosphorous) with excess concentrations. It is necessary to remove the phosphorous through advanced treatment especially in the regions that impose strict regulations on the standards of effluent. The current processes of secondary treatment has limits to the removal of nutrients [1]. Phosphorous role is wide-ranging and rough, that back firstly to the importance of phosphorous in algae growth and for other living organisms, and the lack of phosphorous will be eliminating algae. Therefor wastewater (especially industrial wastewater) treatment must be goal to phosphorous removal in certain processes according to the receiving aqua region [2].

In treatment plants, which include aerobic and anaerobic processes, the sludge has considerable amounts of phosphorous may be useful in some purpose especially for fertilizer. In digested sludge, total phosphorous approximates one percent and one and-a-half percent in thermally dried sludge. That produce an environmental problem must be treat [3]. Therefore, the challenge is to find a feasible and economic material which practice in physical- chemical processes. Not accomplish a far-reaching solution for this problem yet. The main sources of phosphorus are fertilizers, which provide the wastewater with contamination by phosphorous about (10-30 g/l)[4]. Phosphorous may be present in wastewater either in organic or inorganic form. In the industrial sludge and wastewater, the significant constituent is the

*Corresponding Author: aseelmuhy87@gmail.com 
organic phosphorous [2]. Previously, before developing detergents, household wastewater is relatively containing varied compounds of phosphorous. The formula of most intense synthetic detergents include polyphosphates in their structure with percent (12-13) of phosphorus .The research on removing phosphorous from wastewater to date is a special case focused on chemical methods (coagulation /sedimentation processes) or biological technologies. Nevertheless, biological technologies may be not suitable for small scale due to low concentrations of carbons, so that the time and cost in biological methods will be increase [5]. Due to initial cost that involved by physical-chemical methods, we can get alternative process for small industry [6].

In addition, there are additional advantages for physical-chemical methods, one of them ease of use; do not need for a great experience in maintenance, and extra costs that concern with sludge handling will be eliminate because the reuse of the sludge. If a suitable, easily available, economic material will found out for phosphorous removal, the main problem in small-scale application will be solved [7]. Waste management is very important, as there are large quantities of waste and bio solids resulting from human activities [8]. Alum sludge, which is a residue resulting from the coagulation process in a water treatment plant, is one such species therefore many researchers head for reuse of alum sludge in many water treatment applications in last years [9]. Disposal of alum sludge may improve phosphorous removal in a wastewater treatment plant when the alum activities persist [10]. In relation to competition with ionic groups on colloids, $\mathrm{Al}^{3}$ has stronger attraction for phosphorous. Therefore, $\mathrm{Al}^{3}$ phosphate reaction occurs in the suspension that contain phosphate and microorganisms initially, then the reaction with colloids after phosphate precipitation. In the tertiary treatment, when $\mathrm{Al} 3$ is used, the phosphate requirement must be met first previously other requests [11]. That is a convincing reason to choose aluminum-based residues as phosphorous removal substance. Mixture of numerous forms of aluminum hydroxide are available in alum sludge [12]. It is possible to use alum sludge as an adsorbent for phosphorous because aluminum hydroxide is an effective medium for phosphorous [13].

There are several techniques for removing phosphorous from wastewater. These processes can be divided into three categories: biological, physical and chemical, phosphorous removed by a new class of sorbent as polymeric ligand exchanger (PLE), by using zirconium oxides and activated alumina [14], two types of deep-bed filters were used with ferrous sulphate as precipitation agent [15], (90 nm) of natural zeolite modified with lanthanide used as adsorption media [16]. Also using coagulationfiltration to reach a high phosphorous removal efficiency and emphasized practical applicability [1], coagulation and membrane microfiltration also used to remove dissolved phosphorous [17], alum as $\left(\mathrm{Al}_{2} \cdot\left(\mathrm{SO}_{4}\right)_{3} \cdot 18 \mathrm{H}_{2} \mathrm{O}\right)$ used to remove phosphorous in low alkalinity secondary effluent [18], adsorption of phosphorous accomplished

by flocculation upon hydrolysis of alum $\mathrm{A}_{12}\left(\mathrm{SO}_{4}\right)_{3}$ [19]. Two types of dissolved air flocculation DAF were used in nutrients removal: standard air dissolving tank method and modified process with air injection into the suction side of the recirculation pump [20] . This work aims to testing the ability of oven dried alum sludge to remove total phosphorous in wastewater in various concentration and conditions.

Mathematical modeling of biosorption includes both kinetic and equilibrium modeling. Kinetic models describe the history of absorption; while 
equilibrium models describe sorption capacity as a function of chemistry. Empirical models, such as Freundlich and Langmuir isotherms, and theoretical models are used in the equilibrium modeling. The following equation express Langmuir isotherm model:

$q e=q \max b C e / 1+b C e$

Where $q_{e}$ represent contaminant amount which adsorbed at equilibrium ( $\mathrm{mg} / \mathrm{g}$ or $\mathrm{mmol} / \mathrm{g}$ ),

Ce represent contaminant concentration in solution at equilibrium $(\mathrm{mg} / \mathrm{L}$ or $\mathrm{mmol} / \mathrm{L})$,

$q_{\max }$ represent the maximum capacity of adsorption (mg/g or $\mathrm{mmol} / \mathrm{g}$ ),

b represent Langmuir constant associated with adsorption heat ( $\mathrm{L} / \mathrm{mg}$ or $\mathrm{L} / \mathrm{mmol})$.

The following equation describe Freundlich isotherm model

$q e=K f C e 1 / n$

Where $\mathrm{Kf}$ represent Freundlich adsorption constant, $1 / \mathrm{n}$ represent the intensity of adsorption.

Equations (1) and (2) are used to describe the sorption of single component. [21]

\section{Material and Experimental}

\subsection{Oven Dried Alum Sludge}

Prepared by heating an alum sludge (accumulated due to coagulation and sedimentation process in the water treatment plants) in the oven on temperature of (104 C) for (24 hr), then cooled in room temperature and crushed by a mill. Table (1) illustrates the composition of ODAS.
Table 1. alum sludge composition

\begin{tabular}{cc}
\hline Components & Percentage \\
$\mathrm{Al}_{2} \mathrm{O}_{3}$ & $40.1 \%$ \\
$\mathrm{Fe}_{2} \mathrm{O}_{3}$ & $21.7 \%$ \\
$\mathrm{SiO}_{2}$ & $10.8 \%$ \\
$\mathrm{MgO}$ & $3.5 \%$ \\
$\mathrm{Na}_{2} \mathrm{O}$ & $4.6 \%$ \\
$\mathrm{SO}_{3}$ & $1.3 \%$ \\
$\mathrm{~K}_{2} \mathrm{O}$ & $5.3 \%$ \\
$\mathrm{P}_{2} \mathrm{O}_{5}$ & $0.8 \%$ \\
$\mathrm{CaO}$ & $6.4 \%$ \\
$\mathrm{Others}$ & $6.3 \%$ \\
\hline
\end{tabular}

\subsection{Wastewater}

As a sample prepared from sodium phosphate diluted in deionized water to prepare several solutions of phosphorous in order to be able to study the efficiency of the adsorbent material in different concentrations of phosphorus. Table 2 shows the mass of sodium phosphate used to prepare various concentration of phosphorous and Table 3 represent the physical and chemical properties of $\mathrm{Na}_{3} \mathrm{PO}_{4}$

Table 2. Solutions of phosphorous

\begin{tabular}{cc}
\hline P concentration $(\mathbf{m g} / \mathbf{l})$ & $\mathbf{N a}_{\mathbf{3}} \mathbf{P O}_{\mathbf{4}}$ which added $(\mathbf{g})$ \\
\hline 5 & 0.02646 \\
10 & 0.05292 \\
15 & 0.07939 \\
20 & 0.10585 \\
\hline
\end{tabular}

Table 3. Properties of $\mathrm{Na}_{3} \mathrm{PO}_{4}$ [22]

$\begin{array}{cc}\text { Component } & \mathrm{Na}_{3} \mathrm{PO}_{4} \text { which added }(\mathrm{g}) \\ \text { Molecular Weight } & 163.941 \mathrm{~g} / \text { mole } \\ \text { Complexity } & 36.8 \\ \text { Melting point } & 1583^{\circ} \mathrm{C} \\ \text { Solubility } & \text { freely soluble in water } \\ \text { Density } & 2.54 \mathrm{~g} / \mathrm{cm}^{3} \\ \text { pH } & 11.5-12.5\end{array}$




\section{Experimental work}

The experiments of batch work were used to get isothermal equilibrium and later equilibrium for data. The following parameters were studied:

1. The effect of ODAS on the adsorption process,

2. The effect of contact time on the adsorption process,

All results were checked in a shaker with water bath at a temperature of $\left(25^{\circ} \mathrm{C} \pm 1\right)$, mixing speed of $(185 \mathrm{rpm})$ and a contact time of (180 $\min )$.

Flasks of 50 and $100 \mathrm{ml}$ were used in work and phosphorous concentration of $(5,10,15$, and 20) $\mathrm{mg} / \mathrm{l}$ were studied for all conditions.

The dosage of ODAS that used, as adsorbent material was $(20,10,5,2.5,1.25 \mathrm{~g} / \mathrm{l})$ and final phosphorous concentration measured by UVVIS Spectrophotometer as adsorbate.

\section{Results and Discussion}

\subsection{Adsorbent Dose}

The effect of oven-dried-alum-sludge dose on phosphorous adsorption are shown in the following figures:

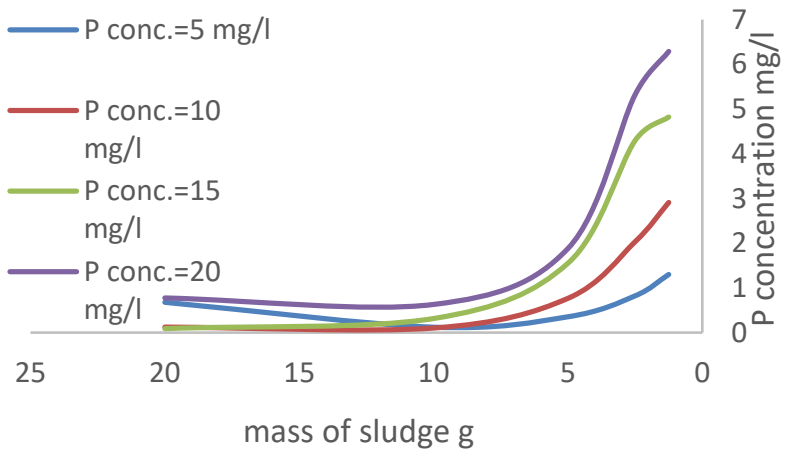

Figure1. The effect of alum sludge dose on $P$ removal.

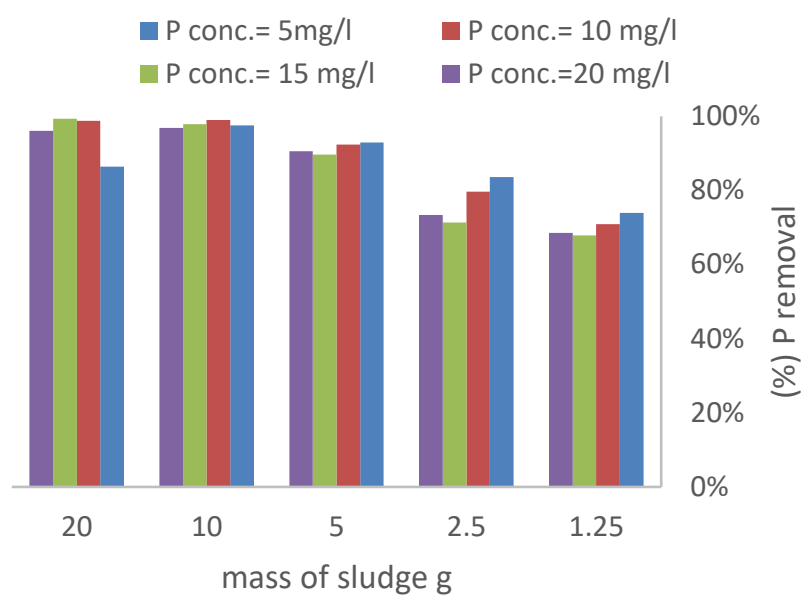

Figure2. Influnce of ODAS on phosphorous removal effeciency

The dose of $(1.25 \mathrm{~g} / \mathrm{l})$ achieved the highest efficiency at concentration $(5 \mathrm{mg} / \mathrm{l})$ and when the dose was doubled to $(2.5 \mathrm{~g} / \mathrm{l})$, it was noticed that the adsorption efficiency began to increase as the highest efficiency rate for removing phosphorous was at concentration $(5 \mathrm{mg} / \mathrm{l})$ as well, even at dose $(5 \mathrm{~g} / \mathrm{l})$.

At dose $(10 \mathrm{~g} / \mathrm{l})$, the removal percentage increased significantly and highly for all concentrations, and phosphorous removal efficiency were obtained $(98 \%, 99 \%, 97 \%, 97 \%)$ for $(5,10,15,20) \mathrm{mg} / \mathrm{l}$ concentrations, respectively. At dose 20, it was observed that at concentration $(5 \mathrm{mg} / \mathrm{l})$, the removal efficiency decreased to $86 \%$, but it remained the same for the rest of the concentrations $(99 \%, 99 \%$, and $94 \%)$. The figures illustrate that the final concentration of phosphorous after adsorption process decrease with the increasing of the weight of ODA. The minimum concentration obtained at dosage of $(10,20) \mathrm{mg} / \mathrm{l}$. Advanced wastewater treatment to remove approximately 61 to 68 percent phosphorus was found to increase capital costs by 42 to 99 percent [4] therefore for more economic purpose $10 \mathrm{mg} / \mathrm{l}$ obtained as the optimum dosage for all experiments. 


\subsection{Contact Time}

The effect of contact time on phosphorous removal are shown in the figures below. The initial contact time obtained as $180 \mathrm{~min}$ to get the optimum dosage of ODAS, and then various periods estimate to check the optimum contact time. The figure below shows that the relationship between contact time and phosphorous concentration after the adsorption process is inversely related, and the higher the contact time, the greater the adsorption efficiency of ODAS.

The figure below shows that removal efficiency is significantly affected when contact time increases and the increase in efficiency was slight from 150 to 180 minutes.

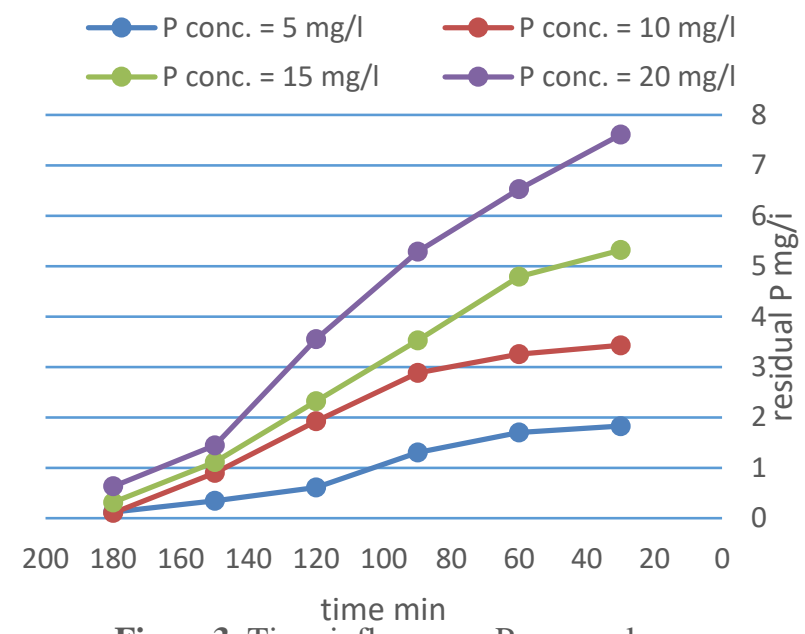

Figure3. Time influnce on P removal

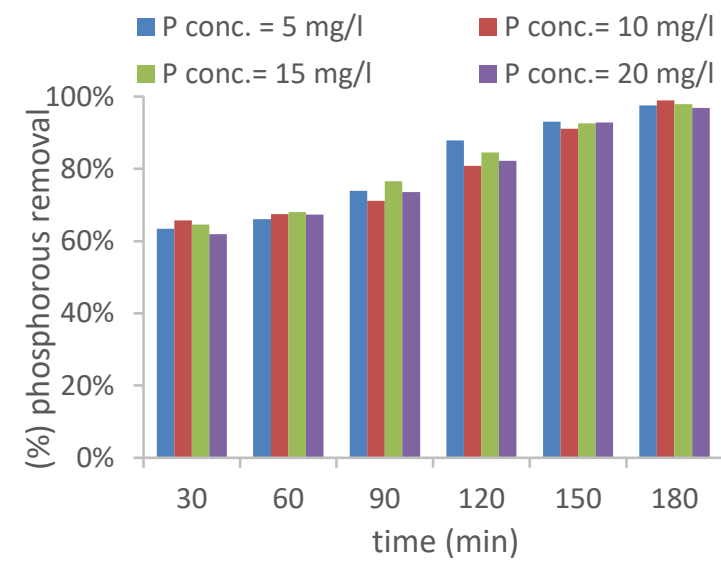

Figure 4. Time effect on $\mathrm{P}$ removal percentage

\subsection{Equilibrium Isotherm Experiments}

Freundlich isotherm curves for $\mathrm{P}$ adsorption on ODAS were get by plotting the solute concentration at equilibrium $\left(\mathrm{C}_{\mathrm{e}}\right)$ against the solute weight that adsorbed per adsorbent weight $\left(\mathrm{q}_{\mathrm{e}}\right)$, and Langmuir isotherm curves get by plotting the solute concentration at equilibrium $\left(\mathrm{C}_{\mathrm{e}}\right)$ against $\mathrm{C}_{\mathrm{e}} /(\mathrm{x} / \mathrm{m})$ whrere,

$\mathrm{x}$ : is the mass of adsorbate adsorbed (mg)

$\mathrm{m}$ : is the mass of adsorbent $(\mathrm{g})$

The following figures illustrate the isotherm curves of phosphorous adsorption with tables of isotherm parameters for $\mathrm{P}$ adsorption.

Fig.5 (a) shows Freundlich isotherm model of phosphorus adsorption at initial concertation 5 $\mathrm{mg} / \mathrm{l}$, and Fig.5 (b) shows Langmuir isotherm model of phosphorus adsorption at same concentration.

Table 4 (a) represent isotherm parameter of Langmuir and Freundlich models for phosphorus adsorption on ODAS at initial concentration of 5 $\mathrm{mg} / \mathrm{l}$.

Table 4 (a). Isotherm parameters for $\mathrm{P}$ adsorption onto ODAS with the correlation coefficient at $\mathrm{P}$ conc. $=5 \mathrm{mg} / \mathrm{l}$

\begin{tabular}{ccc}
\hline model & parameter & value \\
Langmuir & $\mathrm{a}$ & 0.258299 \\
& $\mathrm{~b}$ & 13.3411 \\
& Correlation coefficient & 0.773372 \\
Freundlich & $\mathrm{k}$ & 2 \\
& $\mathrm{n}$ & 0.487039 \\
& Correlation coefficient & 0.992161 \\
\hline
\end{tabular}




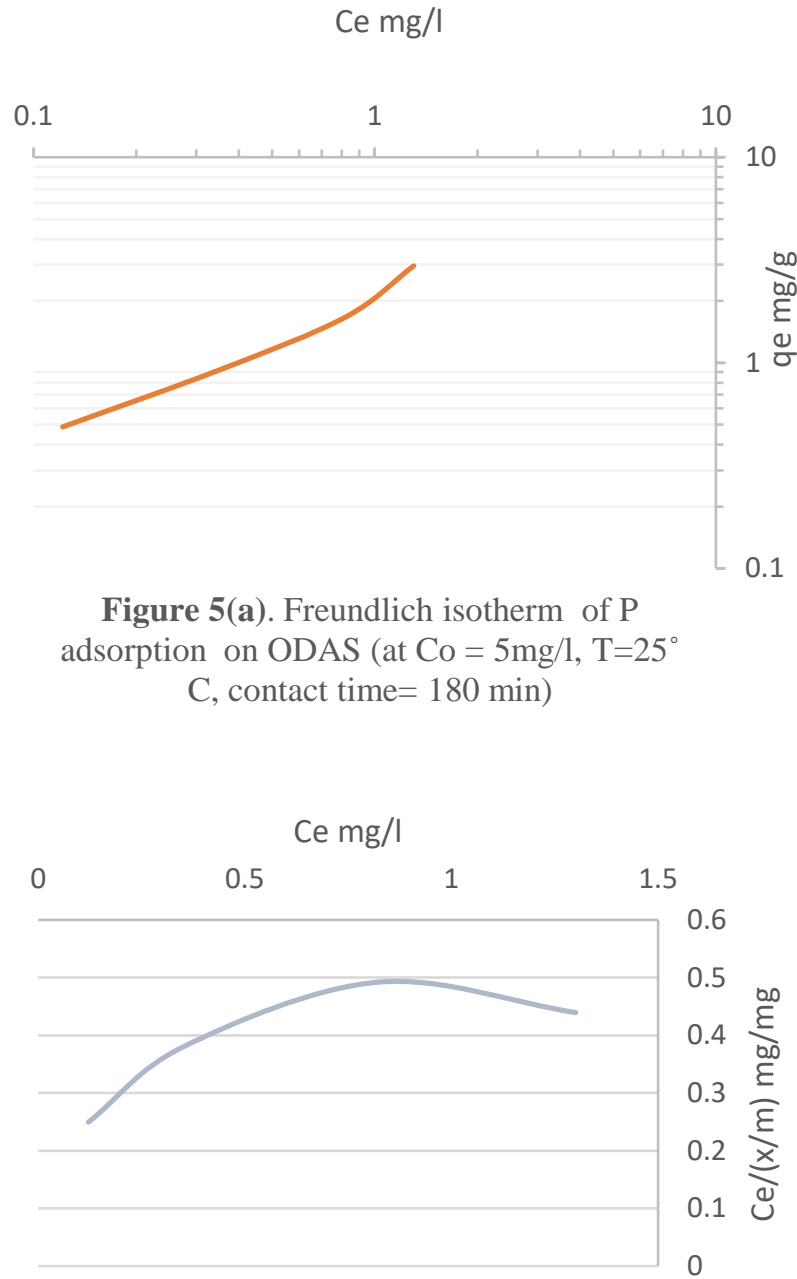

Figure 5 (b). Langmuir isotherm of $\mathrm{P}$ adsorption on ODAS (at $\mathrm{C} 0=5 \mathrm{mg} / \mathrm{l}, \mathrm{T}=25 \mathrm{C}$, contact time $=180 \mathrm{~min}$ )

Fig.6 (a) shows Freundlich isotherm model of phosphorus adsorption at initial concertation 10 $\mathrm{mg} / \mathrm{l}$, and Fig.5 (b) shows Langmuir isotherm model of phosphorus adsorption at same concentration.

Table 4 (b) represent isotherm parameter of Langmuir and Freundlich models for phosphorus adsorption on ODAS at initial concentration of $10 \mathrm{mg} / \mathrm{l}$.
Table 4 (b). Isotherm parameters for P adsorption onto ODAS with the correlation coefficient at $\mathrm{P}$ conc. $=10 \mathrm{mg} / \mathrm{l}$

$\begin{array}{ccc}\text { model } & \text { parameter } & \text { value } \\ \text { Langmuir } & \mathrm{a} & 0.225286 \\ & \mathrm{~b} & 21.54147 \\ & \text { Correlation coefficient } & 0.803754 \\ & \mathrm{k} & 2.1\end{array}$

Freundlich

n

0.633380479

Correlation coefficient

0.973216 
Table 4 (c). Isotherm parameters for $\mathrm{P}$ adsorption onto ODAS with the correlation coefficient at $\mathrm{P}$ conc.$=20 \mathrm{mg} / 1$

\begin{tabular}{ccc}
\hline Model & parameter & Value \\
Langmuir & $\mathrm{a}$ & 15.61764 \\
& $\mathrm{~b}$ & 0.180405 \\
& Correlation coefficient & 0.716708 \\
Freundlich & $\mathrm{k}$ & 2.8 \\
& $\mathrm{n}$ & 0.752095 \\
& Correlation coefficient & 0.916024 \\
\hline
\end{tabular}

The following Fig.7 (a) shows Freundlich isotherm model, and Fig.7 (b) shows Langmuir isotherm model for phosphorus adsorption at initial concertation $15 \mathrm{mg} / \mathrm{l}$.

Table 4 (c) represent isotherm parameter of Langmuir and Freundlich models for phosphorus adsorption on ODAS at initial concentration of $15 \mathrm{mg} / \mathrm{l}$.

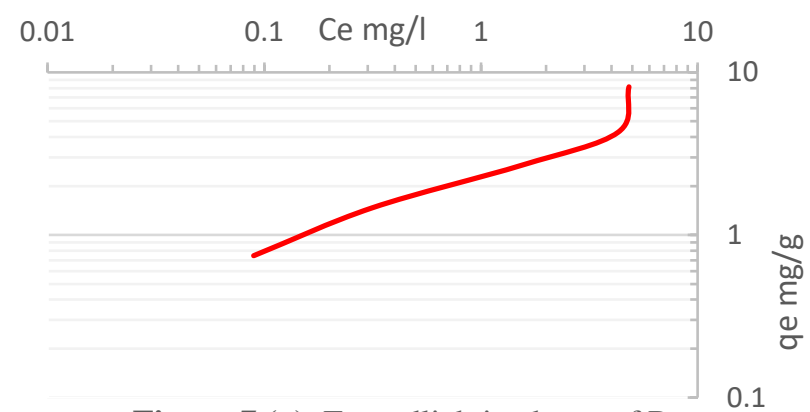

Figure 7 (a). Freundlich isothetm of $\mathrm{P}$ adsorption on ODAS (at $\mathrm{Co}=15 \mathrm{mg} / \mathrm{l}$, $\mathrm{T}=25^{\circ} \mathrm{C}$, contact time $=180 \mathrm{~min}$ )

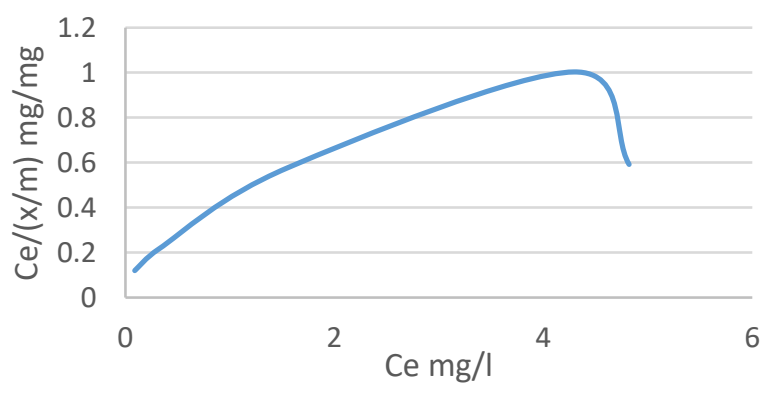

Figure 7 (b). Langmuir isotherm of $\mathrm{P}$ on ODAS (at $\mathrm{Co}=15 \mathrm{mg} / \mathrm{l}, \mathrm{T}=25^{\circ} \mathrm{C}$, contact time $=180 \mathrm{~min}$ )
Fig.8 (a) shows Freundlich isotherm model, and Fig.8 (b) shows Langmuir isotherm model for phosphorus adsorption at initial concertation 20 $\mathrm{mg} /$

Table 4 (d) represent isotherm parameter of Langmuir and Freundlich models for phosphorus adsorption on ODAS at initial concentration of $20 \mathrm{mg} / \mathrm{l}$.

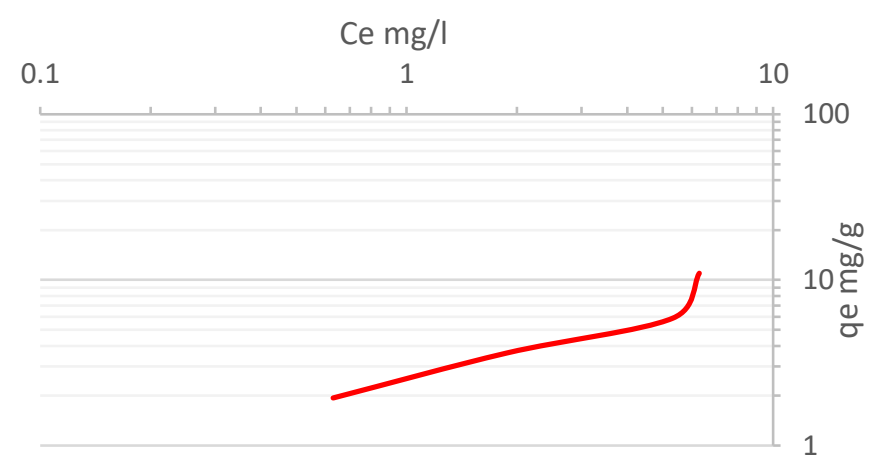

Figure 8 (a). Freundlich isotherm of $\mathrm{P}$ adsorption on ODAS (at $\mathrm{Co}=20 \mathrm{mg} / \mathrm{l}, \mathrm{T}=25^{\circ} \mathrm{C}$, contact time $=180 \mathrm{~min})$

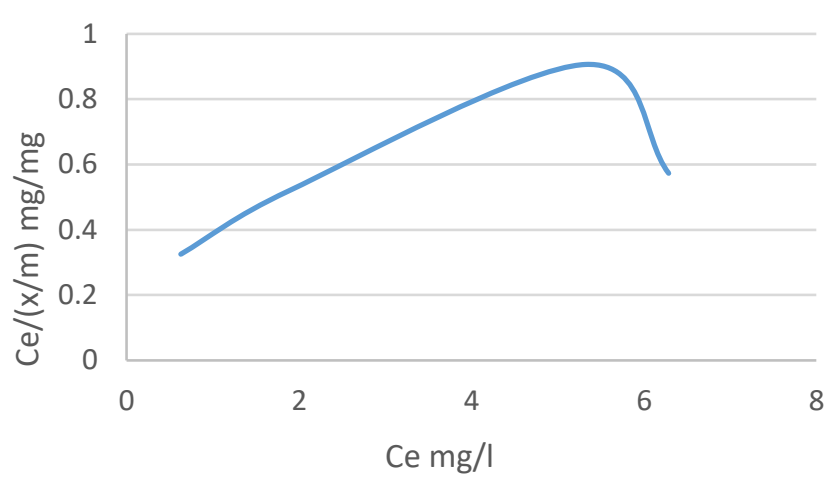

Figure 8 (b). Langmuir isotherm of $\mathrm{P}$ adsorption on ODAS (at $\mathrm{Co}=20 \mathrm{mg} / \mathrm{l}, \mathrm{T}=25^{\circ} \mathrm{C}$, contact time $=180 \mathrm{~min}$ )

Table 4 (d). Isotherm parameters for $\mathrm{P}$ adsorption onto ODAS with the correlation coefficient at $P$

\begin{tabular}{ccc} 
model & parameter & value \\
& $\mathrm{a}$ & 8.929087 \\
Langmuir & $\mathrm{b}$ & 0.387298 \\
& Correlation coefficient & 0.829585 \\
& $\mathrm{k}$ & 2.3 \\
Freundlich & $\mathrm{n}$ & 0.821019459 \\
& Correlation coefficient & 0.919607396 \\
\hline
\end{tabular}




\subsection{FTIR Analysis}

Fourier-transform infrared spectroscopy used to analysis of adsorption media ODAS and the following figures show the adsorption intensity for ODAS before and after the adsorption process.

The following Fig.9 (a) shows the FTIR analysis for ODAS before the adsorption process of phosphorus, and Fig.9 (b) represent FTIR analysis for ODAS after the adsorption process.

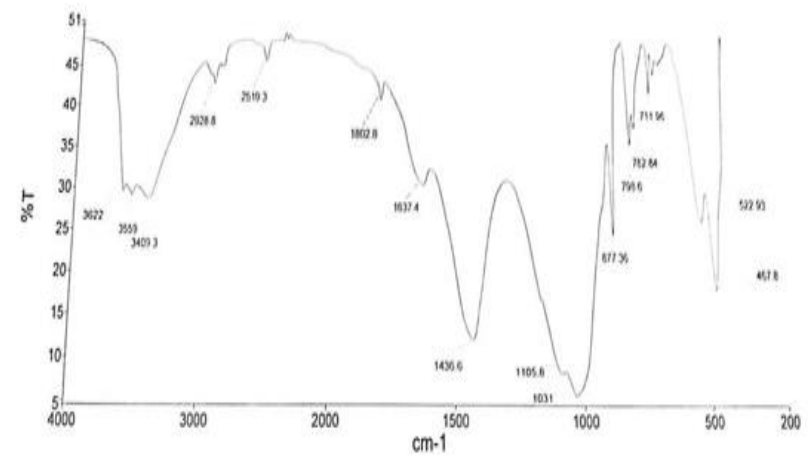

Figure 9 (a). FTIR Analysis for ODAS before P adsorption

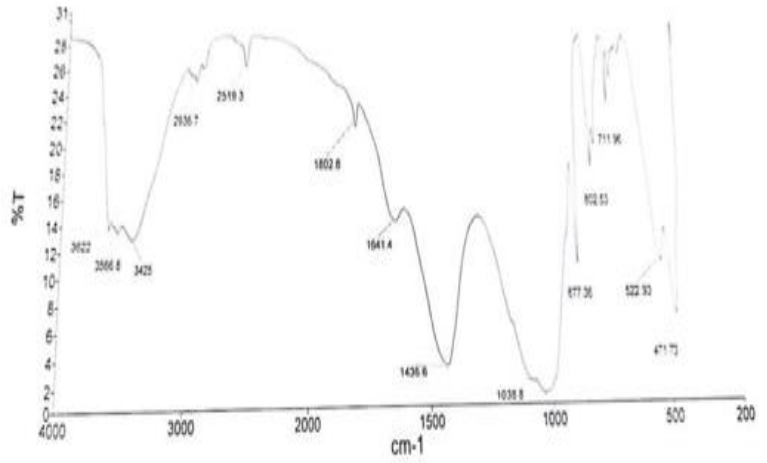

Figure 9 (b). FTIR Analysis for ODAS after P adsorption

\section{Conclusion}

This study has led to the following conclusions:

1) The results showed that the sludge is effective in adsorption of phosphorous from distilled water.

2) The efficiency of phosphorous removal increases with the increasing of ODAS dose at different contact time.
3) There is no obvious and appreciable increase in adsorption efficiency from the dose $10 \mathrm{~g} / \mathrm{l}$ to $20 \mathrm{~g} / \mathrm{l}$.

4) Contact time between the OVEN and phosphorus samples has significant impact on adsorption process.

5) The results showed that the model Freundlich well suited for adsorption capacity, which has the highest value of correlation coefficient.

6) P adsorption on ODAS decreased relative absorption intensity because the existence of hydroxide ions $\left(\mathrm{OH}^{-}\right)$in alum sludge before and after $P$ adsorption.
Abbreviations
$\begin{array}{ll}\text { P } & \text { Phosphorous } \\ \text { ODAS } & \text { oven dried alum sludge }\end{array}$
PLE polymeric ligand exchanger
DAF dissolved air flocculation
FTIR Fourier-transform infrared

\section{Nomenclature}

a Langmuir constant ( $1 / \mathrm{mg})$

b Langmuir constant (mg/g)

$\mathrm{k} \quad$ Freundlich equilibrium constant

n Freundlich constant

$\mathrm{m} \quad$ Mass of solute adsorbent (g)

$\mathrm{q}_{\mathrm{e}} \quad$ Amount of metal ion adsorbed $(\mathrm{mg} / \mathrm{g})$

$\mathrm{m} \quad$ Mass of solute adsorbed (mg)

\section{Conflict of Interest}

The authors confirm that the publication of this article causes no conflict of interest.

\section{References}

1. Weimin X., Qunhui W., Hongzhi M., Yukihide O. \& Hiroaki I. (2005). "Study on phosphorus removal using a 
coagulation system," Process Biochem., vol. 40, no. 8, pp. 2623-2627,

2. Varandani. (2017). "Environmental Engineering Principles and Practices: Water Supply Engineering." Vol. 1.

3. Clair N. Sawyer, Perry L., Gene F., (2003). "Chemistry for EnvironmentalEngineering and Science" $5^{\text {th }}$ ed. p. 768.

4. Joseph A. Salvato, Nelson L., Franklin J. (2005). "Environmental Engineering". $5^{\text {th }}$ ed.

5. Julie L. Zilles, Jordan P, M. Kim, C.H. Hung \& D.R. Noguera. (2002). "Involvement of Rhodocyclus-related organisms in phosphorus removal in fullscale wastewater treatment plants," Appl. Environ. Microbial. vol. 68, no. 6, pp. 2763-2769.

6. Sawsan A. M. Mohammed \& Haider A. Shanshool. (2009). "Phosphorus removal from water and waste water by chemical precipitation using Alum and Calcium Chloride," Iraqi J. Chem. Pet. Eng., vol. 10, no. 2, pp. 35-42.

7. Wadood T. Mohammed \& Sarmad A. Rashid. (2012). "Phosphorus removal from wastewater using oven-dried alum sludge," Int. J. Chem. Eng. vol, 2012.

8. Alexander D. , R. Gnirß \& U. Wiesmann. (2002). "Phosphorus removal with membrane filtration for surface water treatment," Water Sci. Technol., vol. 46, no. 4-5, pp. 257-264.

9. Ruth E Weiner \& Robin A. Matthews. (2012). "Environmental engineering of navigation infrastructure: A survey of existing practices, challenges, and potential opportunities". $4^{\text {th }} \mathrm{ed}$.

10. John C. Crittenden, R. Rhodes T., David W. H. (2012). "MWH's Water Treatment - Principles and Design”. $3^{\text {th }} \mathrm{ed}$.
11. David Hendricks. (1997). "Fundamentals of Water Treatment Unit Processes."

12. M.I. Aguilar, J. S!aez, M. Llor!ens, A. Soler \& J.F. Ortuno .(2002). "Nutrient removal and sludge production in the coagulation-flocculation process," Water Res., vol. 36, no. 11, pp. 2910-2919.

13. Elisabelth G. \& Ronald G. (1997). "Phosphorus removal from wastewaters: Experimental and theoretical support for alternative mechanisms," Water Res., vol. 31, no. 2, pp. 328-338.

14. Dongye Z. \& Arup K. S. (1998). "Ultimate removal of phosphate from wastewater using a new class of polymeric ion exchangers," Water Res., vol. 32, no. 5, pp. 1613-1625.

15. Lena J. Elzbieta P. \& Bengt H. (1997). "Experiences of nitrogen and phosphorus removal in deep-bed filters in the Stockholm area," Water Sci. Technol., vol. 36, no. 1, pp. 183-190.

16. Ning P. Bart H.J. org2, L. Bing, LU Xiwu \& Zhang Y. (2008). "Phosphate removal from wastewater by model-La (III) zeolite adsorbents," J. Environ. Sci., vol. 20, no. 6, pp. 670-674.

17. K. C. Yu , J.S. Chang, I.P. Chen , D. J. Chang, C. Y. Chang \& S. H. Chen (2000) "The removal of colloid and dissolved phosphorus by coagulation and membrane microfiltration", Journal of Environmental Science and Health. vol. 35, no. 9, pp. 1603-1616.

18. R. J. Banu, K. U. Do \& I. T. Yeom. (2008). "Phosphorus removal in low alkalinity secondary effluent using alum," Int. J. Environ. Sci. Technol., vol. 5, no. 1, pp. 93-98.

19. Jean-Philippe B., THI C. TO, Abderrazak B. \& Carmel J. (1997). "Phosphate adsorption in flocculation processes of aluminium sulphate and poly-aluminium- 
silicate-sulphate," Water Res., vol. 31, no. 8, pp. 1939-1946.

20. P. Jokela, E. Ihalainen, J. Heinänen \& M. Viitasaari. (2001). "Dissolved air flotation treatment of concentrated fish farming wastewaters," Water Sci. Technol., vol. 43, no. 8, pp. 115-121.

21. Yun H. P., Sok K., Ho S. K. , Chulhwan Park , \& Yoon-E Choi. (2020). "Adsorption strategy for removal of harmful cyanobacterial species Microcystis aeruginosa using chitosan fiber," Sustain., vol. 12, no. 1.

22. National Center for Biotechnology Information (2021). PubChem Compound Summary for CID 24243, Trisodium phosphate. Retrieved May 26, 2021 . 